\title{
Homer Proteins Regulate Coupling of Group I Metabotropic Glutamate Receptors to N-Type Calcium and M-Type Potassium Channels
}

\author{
Paul J. Kammermeier, ${ }^{1}$ Bo Xiao, ${ }^{2}$ Jian Cheng Tu, ${ }^{2}$ Paul F. Worley, ${ }^{2}$ and Stephen R. Ikeda ${ }^{1}$ \\ ${ }^{1}$ Laboratory of Molecular Physiology, Guthrie Research Institute, Sayre, Pennsylvania 18840, and 2Department of \\ Neuroscience, Johns Hopkins University, School of Medicine, Baltimore, Maryland 21205
}

Group I metabotropic glutamate receptors (mGluR1 and 5) couple to intracellular calcium pools by a family of proteins, termed Homer, that cross-link the receptor to inositol trisphosphate receptors. mGluRs also couple to membrane ion channels via G-proteins. The role of Homer proteins in channel modulation was investigated by expressing mGluRs and various forms of Homer in rat superior cervical ganglion (SCG) sympathetic neurons by intranuclear cDNA injection. Expression of cross-linkingcapable forms of Homer (Homer 1b, 1c, 2, and 3, termed long forms) occluded group I mGluR-mediated N-type calcium and M-type potassium current modulation. This effect was specific for group I mGluRs. mGluR2 (group II)-mediated inhibition of $\mathrm{N}$-channels was unaltered. Long forms of Homer decreased modulation of $\mathrm{N}$ - and $\mathrm{M}$-type currents but did not selectively block distinct G-protein pathways. Short forms of Homer, which cannot self-multimerize (Homer $1 \mathrm{a}$ and a Homer 2 C-terminal deletion), did not alter mGluR-ion channel coupling. When coexpressed with long forms of Homer, short forms restored the mGluR1a-mediated calcium current modulation in an apparent dose-dependent manner. Homer $2 b$ induced cell surface clusters of mGluR5 in SCG neurons. Conversely, a uniform distribution was observed when mGluR5 was expressed alone or with Homer short forms. These studies indicate that long and short forms of Homer compete for binding to mGluRs and regulate their coupling to ion channels. In vivo, the immediate early Homer 1a is anticipated to enhance ion channel modulation and to disrupt coupling to releasable intracellular calcium pools. Thus, Homer may regulate the magnitude and predominate signaling output of group I mGluRs.

Key words: mGluR; Homer; calcium current; M-current; ion channel modulation; neuron; G-protein
Group I metabotropic glutamate receptors (mGluRs) modulate ionic currents in central (Sahara and Westbrook, 1993; Chavis et al., 1994; Glaum and Miller, 1995; Choi and Lovinger, 1996) and peripheral neurons (Hay and Kunze, 1994) by activating pertussis toxin-sensitive and -insensitive G-proteins (Pin and Duvoisin, 1995). Modulation of calcium currents through heterologously expressed group I mGluRs in superior cervical ganglion (SCG) neurons proceeds through a voltage-dependent, $\mathrm{G} \beta \gamma$-mediated (Herlitze et al., 1996; Ikeda, 1996) pathway as well as a voltageindependent pathway (McCool et al., 1998; Kammermeier and Ikeda, 1999). Activation of group I mGluRs also produces inhibition of M-type potassium currents by a G-protein-dependent mechanism (Charpak et al., 1990; Womble and Moises, 1994; Ikeda et al., 1995).

Recently, a new family of proteins, termed Homer, has been described that bind to the intracellular $\mathrm{C}$ terminus of group I mGluRs (Brakeman et al., 1997) and may regulate function of the receptor (Tu et al., 1998; Xiao et al., 1998). Multiple forms of Homer arising from three different genes have been identified (Kato et al., 1998; Sun et al., 1998; Xiao et al., 1998). The first identified Homer protein, now termed Homer 1a, was identified on the basis of its rapid induction by synaptic activity in models of neural plasticity (Brakeman et al., 1997). Homer 1a encodes a single Ena/VASP homology 1 (EVH1) domain that mediates binding to proline-rich sequences in mGluR and other proteins (Brakeman et al., 1997). All subsequently identified Homer proteins additionally encode a $\mathrm{C}$-terminal coiled coil domain, which mediates

\footnotetext{
Received April 24, 2000; revised June 30, 2000; accepted July 6, 2000.

This work was supported by National Institutes of Health Grants GM56180 and NS37615 (S.R.I.), NS10943 (P.J.K.), and DA11742, DA10309, and MH01152 (P.F.W.) We thank Marina King for valuable technical assistance and J.-P. Pin, S. Nakanishi, and B. A. McCool for supplying clones.

Correspondence should be addressed to Stephen R. Ikeda, Guthrie Research Institute, Guthrie Foundation for Education and Research, One Guthrie Square, Sayre, PA 18840. E-mail: sikeda@inet.guthrie.org.

Copyright (C) 2000 Society for Neuroscience $0270-6474 / 00 / 200001-08 \$ 15.00 / 0$
}

self-multimerization between Homer proteins (Xiao et al., 1998), but additional short form cDNAs have been reported (Soloviev et al., 2000). The coiled coil encoding forms of Homer (Homer 1b, 1c, $2 \mathrm{a}, 2 \mathrm{~b}$, and 3 ; collectively termed long forms) are constitutively expressed in many brain regions and are enriched at the postsynaptic density (Tu et al., 1998; Xiao et al., 1998). Long forms of Homer appear to couple group I mGluRs with intracellular inositol trisphosphate receptors ( $\left.\mathrm{IP}_{3} \mathrm{Rs}\right)(\mathrm{Tu}$ et al., 1998). Homer $1 \mathrm{a}$ binds both mGluRs and $\mathrm{IP}_{3} \mathrm{Rs}$ but lacks the coiled coil domain required to cross-link the receptors. Thus, Homer 1a may function as a naturally occurring dominant negative protein to regulate the degree of $\mathrm{mGluR}-\mathrm{IP}_{3} \mathrm{R}$ coupling. Homer proteins may also regulate the coupling between NMDA receptors and intracellular calcium pools through their interaction with Shank proteins ( Tu et al., 1999).

In addition to releasing intracellular calcium, group I mGluRs regulate membrane ion channels and activate MAP kinase pathways (Peavy and Conn, 1998). In this report, the functional effects of Homer were investigated from the perspective of the G-protein pathways that mediate $\mathrm{N}$-type calcium and M-type potassium channel modulation via group I mGluRs. Consistent with previous studies, long and short forms of Homer appeared to compete to regulate the coupling to G-protein-dependent ion channels in a manner contrasting with their regulation of $\mathrm{IP}_{3} \mathrm{R}$ coupling. These studies suggest a mechanism by which Homer proteins can modulate both the magnitude and the predominate output of its effector pathways.

\section{MATERIALS AND METHODS}

Cell isolation and DNA injection. Detailed descriptions of the isolation and injection procedures have been described previously (Ikeda, 1997). Briefly, the superior cervical ganglia were dissected from adult rats and incubated in Earle's balanced salt solution (Life Technologies, Rochelle, MD) containing $0.4 \mathrm{mg} / \mathrm{ml}$ trypsin (Worthington, Freehold, NJ), $0.6 \mathrm{mg} / \mathrm{ml}$ collagenase D (Boehringer Mannheim, Indianapolis, IN), and $0.05 \mathrm{mg} / \mathrm{ml}$ DNase I (Sigma, St. Louis, MO) for $1 \mathrm{hr}$ at $35^{\circ} \mathrm{C}$. Cells were then centrif uged twice, transferred to minimum essential medium (Fisher Sci- 
entific, Pittsburgh, PA), plated, and placed in an incubator at $37^{\circ} \mathrm{C}$ to await DNA injection. Injection of cDNA was performed with an Eppendorf (Madison, WI) 5246 microinjector and 5171 micromanipulator 4-6 hr after cell isolation. Plasmids were stored at $-20^{\circ} \mathrm{C}$ as a $1 \mu \mathrm{g} / \mu \mathrm{l}$ stock solution in $10 \mathrm{~mm}$ Tris and $1 \mathrm{~mm}$ EDTA, pH 8 . Group I mGluR inserts (from J.-P. Pin, Institut National de la Santé et de la Recherche Médicale de Pharmacologie, France) were cloned in the pRK5 vector (Genentech, South San Francisco, CA). mGluR5-myc (myc tag TREQKLISEEDLAR, inserted between amino acids 22 and 23 of rat mGluR5a; construct from J.-P. Pin) was injected at $0.1 \mu \mathrm{g} / \mu \mathrm{l}$. mGluR1a was injected at $0.03 \mu \mathrm{g} / \mathrm{ml}$, mGluR5 at $0.1 \mu \mathrm{g} / \mu \mathrm{l}$, and mGluR2 at $0.04 \mu \mathrm{g} / \mu \mathrm{l}$. The Homer $\mathrm{Zb}$ c-terminal deletion construct $\mathrm{H} 2 \mathrm{~N}$, construct contains the coding sequences for Homer $2 \mathrm{~b}$ amino acids 2-141. All Homer cDNAs were injected at $0.1 \mu \mathrm{g} / \mu \mathrm{l}$, unless otherwise indicated. Neurons were coinjected with "enhanced" green fluorescent protein cDNA $(0.005 \mu \mathrm{g} / \mu \mathrm{l}$; pEGFPN1; Clontech, Palo Alto, CA) to facilitate later identification of successfully injected cells. After injection, cells were incubated overnight at $37^{\circ} \mathrm{C}$, and patch-clamp experiments were performed the following day.

Electrophysiology and data analysis. Patch-clamp recordings were made using 7052 glass (Garner Glass, Claremont, CA). Pipette resistances were 1-3 $\mathrm{M} \Omega$, yielding uncompensated series resistances of 2-7 M $\Omega$. Series resistance compensation of $80 \%$ was used in all recordings. Data were recorded using an Axopatch 200 or 200A from Axon Instruments (Foster City, CA). Voltage protocol generation and data acquisition were performed using custom data acquisition software on an Apple (Cupertino, CA) Macintosh Quadra series computer with a MacAdios II data acquisition board (G. W. Instruments, Somerville, MA). Currents were sampled at $0.5-5 \mathrm{kHz}$, low-pass-filtered at $5 \mathrm{kHz}$ (calcium currents) or $1 \mathrm{kHz}$ (M-currents) using the four-pole Bessel filter in the patch-clamp amplifier, digitized, and stored on the computer for later analysis. Experiments were performed at $21-24^{\circ} \mathrm{C}$ (room temperature). Data analysis was performed using Igor software (WaveMetrics, Lake Oswego, OR). All statistical analyses were performed using StatView software (SAS Institute, Cary, NC). ANOVA, followed by a post hoc test (as appropriate), was used to determine statistical significance on all data sets. $p=0.05$ was used to determine significance.

Solutions. For calcium current recordings, the external (bath) solution contained (in mM): 145 tetraethylammonium (TEA) methanesulfonate (MS), 10 HEPES, 15 glucose, $10 \mathrm{CaCl}_{2}$, and $300 \mathrm{~nm}$ tetrodotoxin, $\mathrm{pH} 7.4$ osmolality $320 \mathrm{mOsm} / \mathrm{kg}$. The internal (pipette) solution contained (in mM): $120 N$-methyl-D-glucamine MS, 20 TEA, 11 EGTA, 10 HEPES, 10 sucrose, $1 \mathrm{CaCl}_{2}, 4 \mathrm{MgATP}, 0.3 \mathrm{Na}_{2} \mathrm{GTP}$, and 14 Tris-creatine phosphate, $\mathrm{pH} \mathrm{7.2,} \mathrm{osmolality} 300 \mathrm{mOsm} / \mathrm{kg}$. For M-current recordings, the external solution contained (in mM): $150 \mathrm{NaCl}, 2.5 \mathrm{KCl}, 10 \mathrm{HEPES}, 1 \mathrm{MgCl}_{2}, 2$ $\mathrm{CaCl}_{2}, 15$ glucose, and $300 \mathrm{nM}$ tetrodotoxin, $\mathrm{pH} \mathrm{7.4,} \mathrm{osmolality} 320$ $\mathrm{mOsm} / \mathrm{kg}$. The internal solution contained (in $\mathrm{mm}$ ): $150 \mathrm{KCl}, 0.1 \mathrm{~K}_{4}$ BAPTA, 10 HEPES, 4 MgATP, and $0.1 \mathrm{Na}_{2}$ GTP, pH 7.2, osmolality 300 $\mathrm{mOsm} / \mathrm{kg}$. The glutamate concentration in all experiments was $100 \mu \mathrm{M}$.

Western blot and microscopic analysis. A detailed description of the Western blot procedure is reported elsewhere (Xiao et al., 1998). Briefly, six SCGs, weighing $\sim 1 \mathrm{mg}$ each, from three rats were pooled in a microfuge tube and sonicated in $200 \mu \mathrm{l}$ of $2 \times$ SDS sample buffer. The SCG homogenates were centrifuged at $14,000 \mathrm{rpm}$ for $10 \mathrm{~min}$. Various amount of supernatants were resolved by SDS-PAGE and transferred to nitrocellulose membranes. The blots were probed with polyclonal Homer antibody (Xiao et al., 1998) and visualized with ECL (New Life Sciences, Inc., Boston, MA). For the surface expression experiments, neurons were prepared and injected as for electrophysiological experiments but were plated on poly-L-lysine-treated glass coverslips. The following day, cells were exposed to the mouse anti-myc antibody (Jackson ImmunoResearch, West Grove, PA), fixed in $4 \%$ paraformaldehyde (Fisher Scientific, Pittsburgh, PA), and subsequently exposed to the fluorescently tagged secondary antibody (anti-mouse Cy3; Jackson ImmunoResearch). Cells were not permeabilized to restrict labeling to surface epitopes. Finally, the cells were mounted on glass slides with Permafluor (Fisher Scientific) and examined using a Zeiss (Thornwood, NY) Axiophot microscope, and the images were captured using Metamorph software (Universal Imaging Corp., West Chester, PA).

\section{RESULTS}

\section{Endogenous expression of Homer proteins in SCG neurons}

As a prelude to studies of Homer effects on mGluR signaling in SCG neurons, we determined whether Homer proteins are expressed endogenously in SCG neurons. Western blot analysis was performed on rat SCG tissue using antibodies directed against Homer 1 (recognizes $1 \mathrm{~b}$ and 1c), Homer 2 (recognizes $2 \mathrm{a}$ and $2 \mathrm{~b}$ ), and Homer 3. The presence of endogenous Homer 2 and Homer 3 was detected by Western blotting, but Homer 1 proteins were not detected (Fig. 1). It is likely that intranuclear cDNA injection resulted in protein levels much higher than those of the endogenously expressed Homer proteins, as indicated by the degree of ion channel modulation and the surface expression pattern ob-

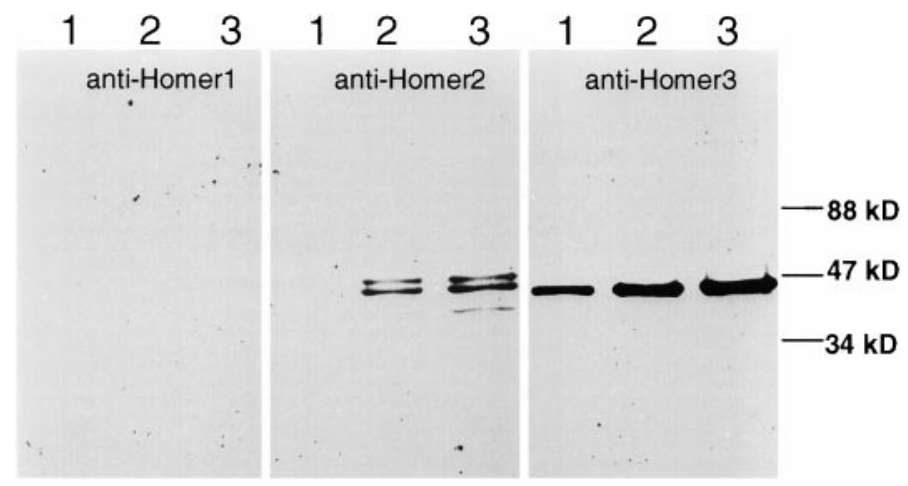

Figure 1. SCG neurons natively express Homer 2 and Homer 3 but not Homer 1. SCG extracts were examined for expression of Homer isoforms. Antibodies were directed against Homer proteins derived from each gene. The anti-Homer1 antibody (left) recognized Homer $1 \mathrm{~b}$ and Homer 1c. Anti-Homer2 (center) recognized Homer $2 \mathrm{~b}$, and anti-Homer3 (right) recognized Homer 3. Five, 10, and $15 \mu \mathrm{l}$ of SCG extract were loaded into lanes 1,2 , and 3 of each group, respectively. The immunoblots were probed with Homer 1-, 2-, and 3-specific antibody.

served in cells heterologously expressing only the receptor (see below). Therefore, natively expressed Homer $2 \mathrm{~b}$ and Homer 3 were unlikely to confound the following experiments.

\section{Long-form Homer results in surface clusters of mGluR}

SCG neurons do not natively express functional mGluRs (Ikeda et al., 1995). This "null background" provides a system whereby specific mGluR subtypes can be heterologously expressed and studied in isolation. To examine the surface expression of a heterologously expressed group I mGluR, mGluR5a containing an extracellular myc tag (mGluR5-myc) was expressed in SCG neurons. Live mGluR5-myc-expressing cells were then exposed to primary anti-myc antibody, fixed in $4 \%$ paraformaldehyde, and exposed to a fluorescently tagged secondary antibody (anti-mouse Cy3) without permeabilization. SCG neurons heterologously expressing mGluR5-myc showed a diffuse receptor distribution (Fig. 2, right). Coexpression of Homer 1a did not appear to alter mGluR5-myc surface expression (data not shown). However, coexpression of Homer 2b with mGluR5-myc appeared to produce a punctate receptor distribution (Fig. 2, left), but surface expression remained high. These data indicate that the long forms of Homer can aggregate group I mGluRs into clusters on the membrane. This clustering is likely to be a function of the coiled coil C-terminal tail present in the long forms of Homer (Xiao et al., 1998), because Homer 1a did not produce the pattern. These changes in group I mGluR distribution suggest that the function of these receptors may also be altered by expression of Homer proteins. Therefore, the effect of Homer expression on group I mGluR-mediated modulation of N-type calcium and M-type potassium currents was examined.

\section{Long forms of Homer proteins reduce group I mGluR-mediated N-type calcium current inhibition}

When mGluR1a was expressed in SCG neurons, application of 100 $\mu \mathrm{M}$ glutamate produced a $55 \pm 4 \%$ (average inhibition $\pm \mathrm{SEM} ; n=$ 15) inhibition of the calcium current (Fig. $3 A$ ). Currents were elicited with a triple-pulse protocol (Elmslie et al., 1990) consisting of a test pulse to $+10 \mathrm{mV}$ (the "prepulse"; indicated in Fig. $3 A$, filled circles), followed by a strong depolarizing step to $+80 \mathrm{mV}$, and another test pulse to $+10 \mathrm{mV}$ (the "postpulse"; Fig. 3A, open circles). Glutamate produced a strong inhibition of the current in the prepulse as well as a slight slowing of activation. The depolarizing step to $+80 \mathrm{mV}$ produced partial relief of inhibition and restored "normal" activation kinetics to the postpulse current. These features of inhibition are hallmarks of modulation produced by activated G-protein $\beta \gamma$ subunits (Hille, 1994), presumably binding directly to the channel (DeWaard et al., 1997). Inhibition by glutamate was typically fully reversible and quite rapid (Fig. $3 A$ ). 


\section{mGluR5+Homer2b}

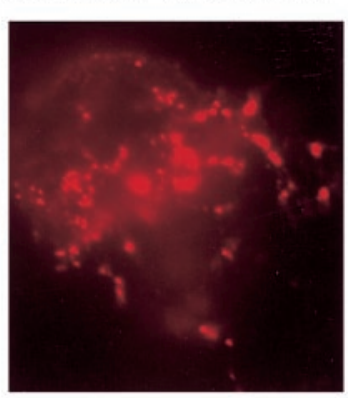

B

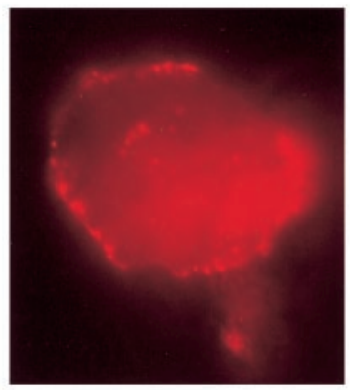

C

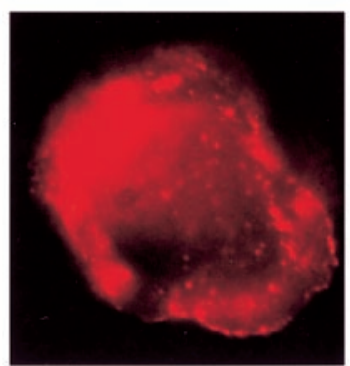

mGluR5
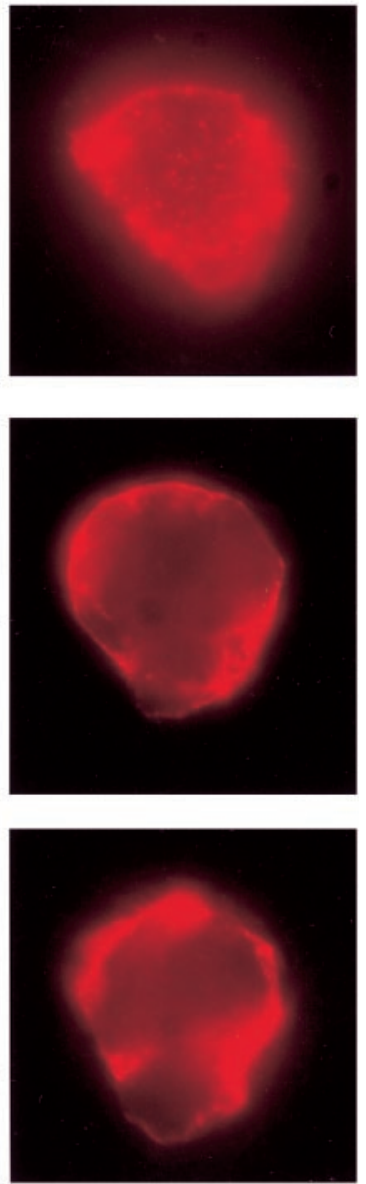

Figure 2. Homer $2 \mathrm{~b}$ expression induces clustering of mGluR5-myc. Left, Surface expression pattern of three cells $(A-C$ represent different focusing plains) expressing mGluR5-myc and Homer 2b. Right, Surface expression pattern of three cells $(A-C)$ expressing mGluR5-myc alone.

The effect of expressing different Homer forms on calcium current inhibition mediated by two group I mGluRs, mGluR1a and mGluR5a (Fig. 3B-D), was tested. Coexpression of Homer 1a with mGluR1a had no effect on calcium current modulation by glutamate (Fig. 3B,D). In cells expressing both mGluR1a and Homer 1a, glutamate inhibited calcium current by $53 \pm 6 \%(n=11)$, similar to cells expressing mGluR1a alone. In addition, an N-terminal construct of Homer 2b was also without significant effect on calcium current inhibition by glutamate. This construct $(\mathrm{H} 2 \mathrm{~N})$ possesses the mGluR binding site common to all Homers but lacks the coiled coil C-terminal tail, making it functionally equivalent to Homer 1a (Xiao et al., 1998). In cells expressing mGluR1a and $\mathrm{H} 2 \mathrm{~N}$, calcium current was inhibited $62 \pm 6 \%(n=5)$ by $100 \mu \mathrm{M}$ glutamate (Fig. $3 D$ ). In contrast, Homer homologs containing the $\mathrm{C}$-terminal coiled coil significantly reduced the modulation of calcium current by glutamate (ANOVA, $p=0.05$; Fig. $3 C, D$ ). Figure $2 C$ illustrates current traces from a cell expressing mGluR1a and Homer 2b. Note that application of glutamate produced virtually no inhibition in this example. On average, calcium current was inhibited $13 \pm 2 \%(n=17)$ in cells expressing mGluR1a and Homer 2b. Similarly, when Homer 3 was coexpressed, glutamate produced only a $13 \pm 5 \%(n=6)$ inhibition. Expression of Homer $1 \mathrm{~b}$ and Homer $1 \mathrm{c}$ yielded intermediate effects, significantly reducing the calcium current inhibition to $38 \pm 4 \%(n=14)$ and $21 \pm$ $6 \%(n=8)$, respectively. Experiments with mGluR5a produced similar results. Cells expressing mGluR5a, mGluR5a plus Homer $1 \mathrm{a}$, and mGluR5a plus Homer $2 \mathrm{~b}$ were inhibited $43 \pm 5 \%(n=6)$, $42 \pm 4 \%(n=5)$, and $11 \pm 2 \%(n=6)$ by $100 \mu \mathrm{M}$ glutamate, respectively (Fig. $3 D$, hatched bars).
The presence of natively expressed long forms of Homer and the ability of these proteins to occlude group I mGluR-mediated calcium channel modulation raised the question of whether group I mGluRs are endogenously expressed at low levels but with their effects masked by the presence of endogenous Homer 2 and Homer 3. To test for this possibility, Homer 1a and $\mathrm{H} 2 \mathrm{~N}$ were expressed alone in cells, without injection of mGluR cDNAs. In six cells expressing Homer 1a alone and in six cells expressing $\mathrm{H} 2 \mathrm{~N}$ alone, no detectable calcium current inhibition was observed after application of $100 \mu \mathrm{M}$ glutamate (data not shown). These data indicate that although SCG neurons express Homer 2 and Homer 3 proteins, they do not appear to natively express functional mGluRs.

\section{Expression of Homer protein does not alter signaling via mGluR2}

Homer proteins are known to bind specifically to group I mGluRs (Brakeman et al., 1997). As a test for specificity, the effect of Homer expression on calcium current inhibition mediated by mGluR2, a group II mGluR, was tested. Expression of mGluR2 in SCG neurons produced a potent, strongly voltage-dependent inhibition of the calcium current (Fig. $4 A$ ). On average, mGluR2mediated calcium current inhibition was $64 \pm 2 \%(n=7$; Fig. $4 D)$. Cells expressing mGluR2 plus Homer 1a (Fig. 4B), Homer 2b, or Homer 3 (Fig. $4 C$ ) exhibited calcium current inhibitions of $54 \pm$ $5 \%(n=9), 57 \pm 4 \%(n=6)$, and $71 \pm 1 \%(n=5)$, respectively (Fig. $4 D)$. Neither the kinetics nor the voltage dependence of mGluR2-mediated calcium current inhibition appeared to be altered by Homer expression. These data indicate that the effects of various forms of Homer on mGluR1a and mGluR5a calcium current modulation result from selective association with group I mGluRs.

\section{Effects on mGluR-mediated modulation by Homer 2b are reversed by coexpression of short-form Homer proteins}

The data above demonstrate that the long and short forms of Homer have contrasting effects. The long forms reduce calcium current modulation, whereas the short forms (Homer 1a and the $\mathrm{H} 2 \mathrm{~N}$ construct) are permissive. Because the mGluR binding site on each form of Homer is well conserved (Brakeman et al., 1997; Xiao et al., 1998), the opposing Homer isoforms may be competing for a shared mGluR binding site. Therefore, the ability of the short forms of Homer to reverse the occlusion by Homer $2 b$ was examined. In cells expressing mGluR1a and Homer $2 \mathrm{~b}$, coexpression of Homer 1a (Fig. $5 B$ ) or $\mathrm{H} 2 \mathrm{~N}$ (Fig. $5 C$ ) was able to significantly increase calcium current inhibition compared with cells expressing mGluR1a and Homer $2 \mathrm{~b}$ alone (ANOVA, $p=0.05$ ). Inhibition was increased from $13 \pm 2 \%(n=17)$, in mGluR1a plus Homer 2b-expressing cells to $21 \pm 2 \%(n=13)$ and $33 \pm 3 \%(n=7)$ in cells coexpressing Homer 1a or $\mathrm{H} 2 \mathrm{~N}$, respectively (Fig. $5 D)$. When Homer 1a cDNA was injected at a twofold higher concentration $(0.2 \mu \mathrm{g} / \mu \mathrm{l})$, presumably inducing higher expression levels, calcium current inhibition was increased further to $35 \pm 2 \%(n=8 ; p<$ $0.05)$. This apparent concentration dependence argues for competition for the mGluR1a binding site. These data suggest that Homer 1a displays a dominant negative phenotype.

Interestingly, cells expressing mGluR1a, Homer $2 \mathrm{~b}$, and Homer $1 \mathrm{~b}$ also displayed significantly more calcium current inhibition by glutamate than the mGluR1a plus Homer 2b-expressing cells (inhibition was increased to $33 \pm 5 \% ; n=9$; Fig. $5 D$ ). This result was unexpected, because expression of Homer $1 \mathrm{~b}$ alone reduced glutamate inhibition of calcium current via mGluR1a (see Fig. 3D). One interpretation of this result is that Homer $1 \mathrm{~b}$ can compete with Homer $2 \mathrm{~b}$ for the mGluR binding site, but that receptors bound to Homer $1 \mathrm{~b}$ are occluded less efficiently than those bound to Homer 2b.

\section{Homer proteins reduce mGluR1a modulation of M-current}

M-type potassium current is a noninactivating, delayed rectifiertype potassium current present in many neuronal cell types (Brown 
A
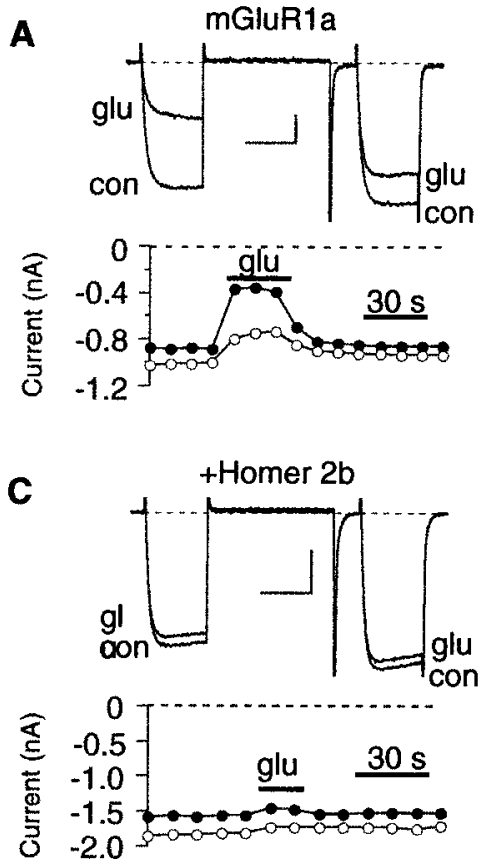

B
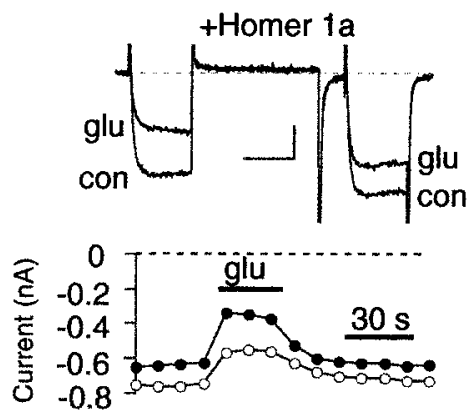

$\%$ Inhibition

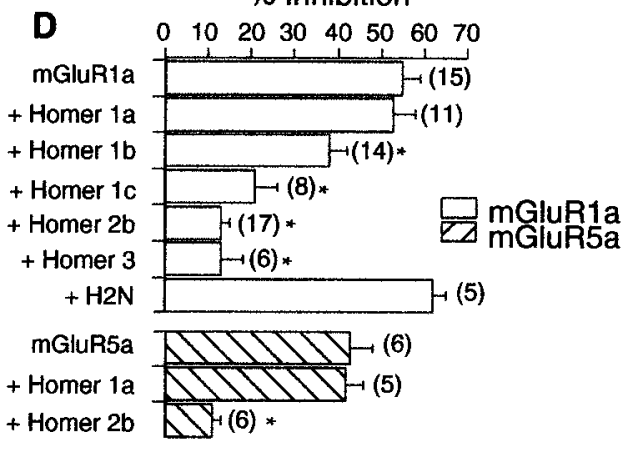

Figure 3. The long but not the short forms of Homer reduce calcium current inhibition through group I mGluRs. A, Sample currents (top) and time course (bottom) illustrating inhibition by 100 $\mu \mathrm{M}$ glutamate in a cell expressing mGluR1a. Cells were held at $-80 \mathrm{mV}$ and stepped to a +10 $\mathrm{mV}$ test pulse for $25 \mathrm{msec}$ and then to a $50 \mathrm{msec}$ $+80 \mathrm{mV}$ conditioning pulse, followed by a brief step back to the holding potential and another test pulse to $+10 \mathrm{mV}$. In the time course, filled circles represent current measurements $10 \mathrm{msec}$ into the first test pulse, the prepulse; open circles represent measurements from the postpulse. Calibration: $0.2 \mathrm{nA}, 20 \mathrm{msec}$. B, Sample currents and time course for a cell expressing mGluR1a and Homer 1a. Calibration: $0.2 \mathrm{nA}, 20 \mathrm{msec}$. $C$, Currents and time course for a cell expressing mGluR1a and Homer 2b. Calibration: $0.5 \mathrm{nA}, 20 \mathrm{msec} . D$, Summary of data from mGluR1a (open bars) and mGluR5a (hatched bars) cells. Error bars represent mean + SEM. The number of cells is indicated in parentheses to the right of each bar. *Statistically significant differences versus controls (ANOVA, $p=0.05$ ). glu, Glutamate; con, control.
A

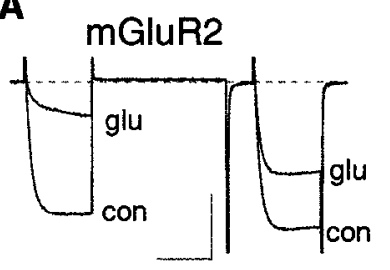

B

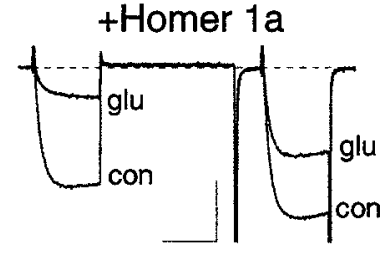

D

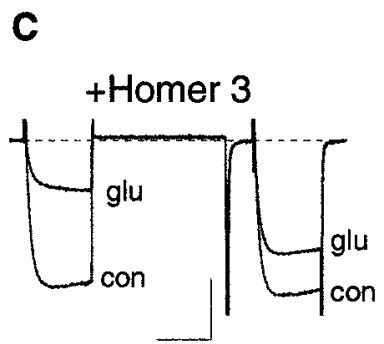

A

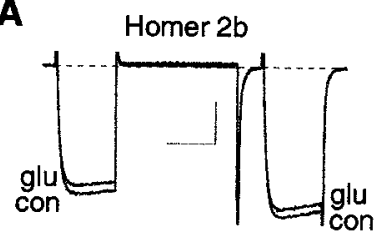

C

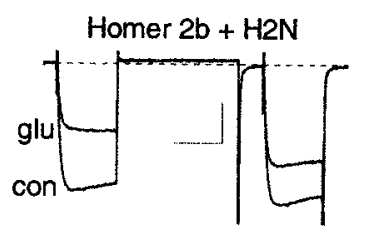

B

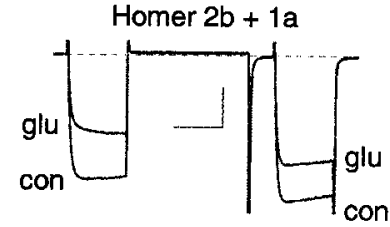

$\%$ Inhibition

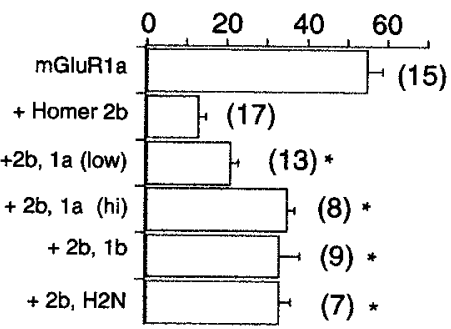

Figure 4. Homer does not alter modulation through mGluR2. $A-C$, Sample currents for inhibition by $100 \mu \mathrm{M}$ glutamate in cells expressing mGluR2 $(A)$, mGluR2 plus Homer 1a $(B)$, and mGluR2 plus Homer $3(C)$. Calibration: $A, 1 \mathrm{nA} ; B, C, 0.7 \mathrm{nA} ; A-C, 20 \mathrm{msec} . D$, Summary of all mGluR2 data. No group produced a level of inhibition that differed from control $(p=0.05$, ANOVA). glu, Glutamate; con, control.

and Adams, 1980; Wang et al., 1998). Modulation of the M-current is believed to play an important role in the regulation of cell excitability (Marrion, 1997). The M-current modulatory pathway by glutamate in SCG neurons (Kammermeier and Ikeda, 1999), as well as by different neurotransmitters (Haley et al., 1998), appears to be initiated by activation of $\mathrm{G} \alpha_{\mathrm{q} / 11}$. To examine the effect of Homer expression on this pathway, M-current modulation was observed in the absence and presence of several forms of Homer. Cells were held at $-30 \mathrm{mV}$ and stepped negatively to $-60 \mathrm{mV}$ for $500 \mathrm{msec}$. M-current was measured as the difference in current at the beginning and end of the step to $-60 \mathrm{mV}$. Application of 100 $\mu \mathrm{M}$ glutamate to SCG neurons expressing mGluR1a produces a $66 \pm 4 \%(n=17)$ inhibition of M-type potassium current (Fig. $6 A)$. Note that with application of glutamate, M-current was quickly inhibited and partially reversed during washout of the drug (see time course; Fig. 6A, bottom). As with calcium current inhi-

Figure 5. The effect of Homer $2 \mathrm{~b}$ can be partially reversed by coexpression of other forms of Homer. $A$, Sample currents illustrating inhibition by 100 $\mu \mathrm{M}$ glutamate in a cell expressing mGluR1a and Homer $2 \mathrm{~b}$ (same cell as in Fig. $1 C$ ). Calibration: $0.5 \mathrm{nA}, 20 \mathrm{msec}$. $B$, Sample currents for a cell expressing mGluR1a, Homer 2b, and Homer 1a. Calibration: $0.5 \mathrm{nA}, 20$ msec. $C$, Sample currents for a cell expressing mGluR1a, Homer 2b, and H2N. Calibration: $0.7 \mathrm{nA}, 20 \mathrm{msec}$. $D$, Data summary for control cells (mGluR1a only, from Fig. $3 D$ ), Homer 2 b cells (cells expressing mGluR1a plus Homer $2 \mathrm{~b}$ ), and those coexpressing Homer $1 \mathrm{a}$ injected at $0.1 \mu \mathrm{g} / \mu \mathrm{l}$ $[+2 b, 1 a($ low $)], 0.2 \mu \mathrm{g} / \mu \mathrm{l}[+2 b, 1 a(h i)]$, Homer $1 \mathrm{~b}(+2 b, 1 b)$, and H2N $(+2 b, H 2 N)$. Data are mean + SEM. * Significant divergence from Homer $2 \mathrm{~b}$ only cells (ANOVA, $p=0.05$ ). In addition, inhibition in the $+2 b 1 a$ (hi) group was significantly larger than in the $+2 b 1 a$ (low) group. glu, Glutamate; con, control.

bition, coexpression of Homer $1 \mathrm{a}$ or $\mathrm{H} 2 \mathrm{~N}$ had no effect on M-current modulation by glutamate in mGluR1a-expressing cells [inhibition was $71 \pm 4 \%(n=6)$ and $63 \pm 9 \%(n=6)$ for Homer $1 \mathrm{a}$ and $\mathrm{H} 2 \mathrm{~N}$, respectively; Fig. $6 B, D$ ]. In contrast, coexpression of Homer $2 \mathrm{~b}$ or Homer 3 was able to reduce M-current modulation (Fig. $6 C, D$ ). However, these long forms of Homer were less effective at blocking the modulation of M-current than of calcium current. When Homer 2b cDNA was injected at $0.1 \mu \mathrm{g} / \mu \mathrm{l}$, M-current inhibition was reduced to only $51 \pm 6 \%(n=6$; not a significant reduction, $p=0.067)$, whereas similar injections of 
A
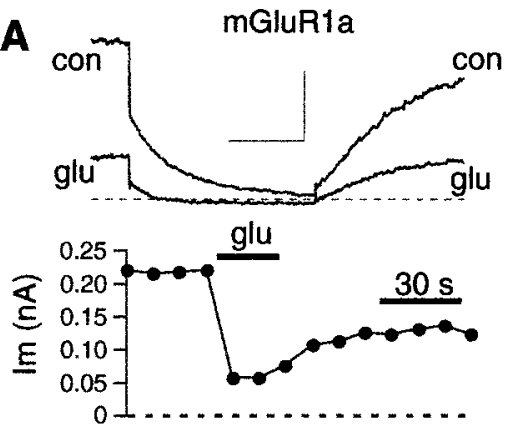

Figure 6. Long forms of Homer can occlude M-current modulation. $A-C$, Sample current traces and time courses from M-current inhibition by glutamate in cells expressing mGluR1a $(A)$, mGluR1a plus Homer 1a $(B)$, and mGluR1a plus Homer 2b $(C)$. Cells were held at $-30 \mathrm{mV}$ and stepped to $-60 \mathrm{mV}$ for $500 \mathrm{msec}$ every $10 \mathrm{sec}$. M-current in each time course was taken as the difference in current at the start and end of the step to $-60 \mathrm{mV}$ as M-type channels deactivated. Calibration: $A$, $0.2 \mathrm{nA} ; B, C, 0.1 \mathrm{nA} ; A-C, 20 \mathrm{msec} . D$, Summary of M-current modulation data. *Statistical significance $(p=0.05)$ compared with control (mGluR1a alone). glu, Glutamate; con, control.

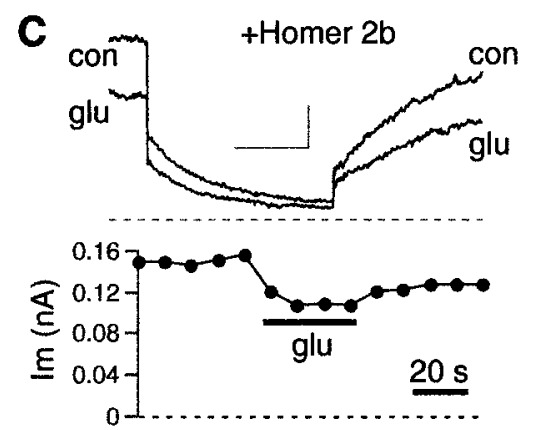

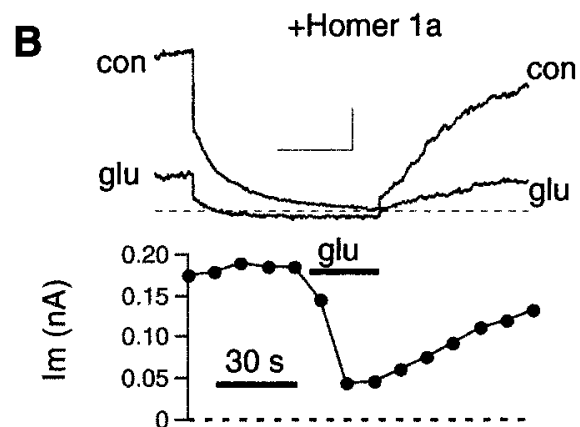

D

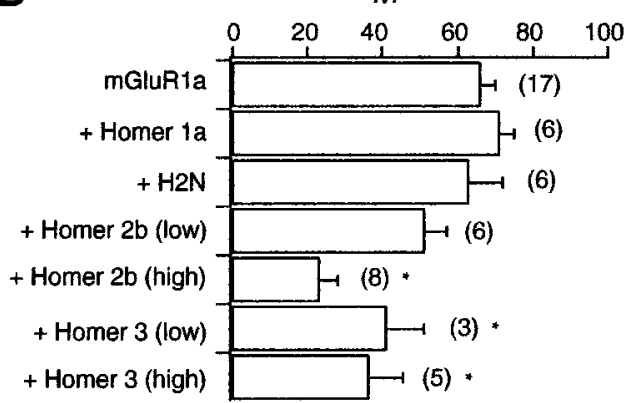

Homer 2b strongly reduced calcium current modulation (mGluR1a cDNA concentration was $0.03 \mu \mathrm{g} / \mu \mathrm{l}$ in all experiments; see Fig. $3 C, D$ ). Increasing injected Homer $2 \mathrm{~b}$ cDNA levels threefold (to 0.3 $\mu \mathrm{g} / \mu \mathrm{l})$ significantly decreased M-current modulation via mGluR1a to $23 \pm 5 \%(n=8$; Fig. $6 C, D)$. Coinjection of 0.1 and $0.3 \mu \mathrm{g} / \mu \mathrm{l}$ Homer 3 cDNA reduced M-current inhibition by glutamate to $41 \pm$ $10 \%(n=3)$ and $36 \pm 9 \%(n=5)$, respectively. These data indicate that the long forms of Homer can reduce signaling of mGluR1a to the M-channel. However, this effect requires higher levels of Homer plasmid injection than the analogous effect on calcium current inhibition.

\section{Effects of Homer proteins on the $G_{i / o}$ and $\mathbf{G}_{\mathrm{q} / 11}$ pathways}

Because the modulation of M-current via group I mGluRs proceeds through a $\mathrm{G}_{\mathrm{q} / 11}$-mediated pathway (Kammermeier and Ikeda, 1999), and moderate levels of Homer seem to discriminate between $\mathrm{M}$-type potassium and $\mathrm{N}$-type calcium current modulation, one can speculate that the long forms of Homer preferentially occlude activation of $\mathrm{G}_{\mathrm{i} / \mathrm{o}}$ over $\mathrm{G}_{\mathrm{q} / 11}$ by mGluRs. As discussed above (see introductory remarks), group I mGluRs activate both the $G_{i / o}$ and $G_{q / 11}$ classes of G-proteins. Activation of $G_{i / o}$ G-proteins by group I mGluRs initiates a voltage-dependent inhibition mediated by G-protein $\beta \gamma$ subunits (Herlitze et al., 1996; Ikeda, 1996). This form of channel modulation is identifiable by the slowing of activation kinetics and partial reversal of inhibition after strong depolarizations (Bean, 1989; Elmslie et al., 1990). In addition, group I mGluRs in SCG neurons inhibit calcium currents through activation of $\mathrm{G}_{\mathrm{q} / 11}$ (Kammermeier and Ikeda, 1999). This form of modulation is readily distinguished from the $G_{i / o}, G \beta \gamma$ mediated inhibition, because it does not exhibit voltage dependence or slowing of activation kinetics. Therefore, relative changes in activation of the $G_{i / o}$ and $G_{q / 11}$ pathways can be monitored by examining the voltage dependence of group I mGluR-mediated calcium current inhibition. To test the possibility that Homer expression selectively influences G-protein activation by mGluR1a, the percent inhibition of postpulse currents (in which voltagedependent inhibition would be partially relieved) was plotted against that of currents in the prepulse, and the voltage dependence of inhibition was determined from the slope of the resulting curve. For this type of analysis, voltage-dependent inhibition would produce a flatter slope, whereas voltage-independent inhibition would
A

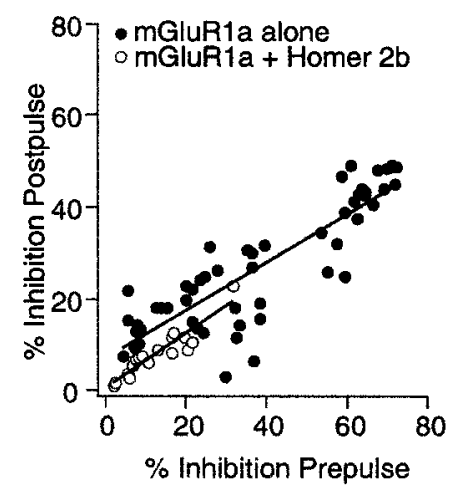

B

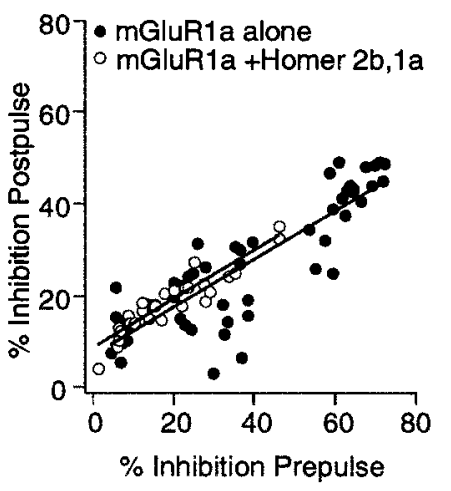

Figure 7. Homer does not alter the voltage dependence of calcium current inhibition by glutamate. $A$, Postpulse versus prepulse inhibition plot for glutamate inhibition in cells expressing mGluR1a (filled circles) and mGluR1a plus Homer 2b (open circles). In this plot, slope is inversely proportional to voltage dependence. Slopes for mGluR1a and mGluR1a plus Homer $2 b$ were $0.52 \pm 0.09$ and $0.60 \pm 0.13$ (slope $\pm 95 \%$ confidence interval). These values were not significantly different. $B$, Similar plot as in $A$, but for mGluR1a cells and cells expressing mGluR1a, Homer $2 \mathrm{~b}$, and Homer $1 \mathrm{a}$. The slopes were $0.52 \pm 0.09$ and $0.53 \pm 0.09$, respectively. Solid lines represent linear regressions to each data set.

have a slope of $\sim 1$ (Kammermeier and Ikeda, 1999). Inhibition data from cells expressing mGluR1a alone and those expressing mGluR1a plus Homer $2 \mathrm{~b}$ appear to have similar slopes, indicating that the voltage dependence is not altered (Fig. $7 A$ ). Therefore, signaling of both G-protein pathways activated by group I mGluRs is similarly inhibited by Homer $2 b$.

A related question concerning mGluR signaling is whether "naked" mGluRs behave similarly to those bound to Homer 1a (or $\mathrm{H} 2 \mathrm{~N}$ ). The data indicate that the magnitude of maximal inhibition is not altered by the short forms of Homer. But is there a change in G-protein coupling? This question can be addressed by examining the voltage dependence of glutamate inhibition in cells injected with mGluR1a alone versus cells injected with mGluR1a, Homer 2b, and Homer 1a (or H2N). Cells injected with mGluR1a alone would be expected to represent naked receptors (unbound to Homer), because the receptors are overexpressed. Those injected 
with mGluR1a and Homer 2b plus Homer 1a (or H2N) represent a nearly pure population of mGluR1a-Homer 1a (or $\mathrm{H} 2 \mathrm{~N}$ ) receptors, because under these conditions Homer 1a is required to "protect" receptors from the effects of Homer $2 \mathrm{~b}$. When the voltage dependence of glutamate inhibition in these two groups was compared, it was found to be identical (Fig. 7B). This indicates that receptors bound to the short form of Homer appear to act similarly to naked receptors.

\section{DISCUSSION}

This study provides evidence that the long forms of Homer act functionally to occlude signaling from group I mGluRs to G-proteins that regulate N-type calcium and M-type potassium channels. The natural immediate early gene form of Homer (short form), as well as a structural homolog, act competitively to reverse the effects of long forms of Homer. Accordingly, the immediate early gene functions as a natural antagonist of long forms of Homer. Because Homer 1a is dynamically expressed in many models of developmental and activity-dependent plasticity, its physiological antagonism of constitutively expressed long Homers provides a mechanism to regulate group I mGluR signaling to ion channels.

Although the mechanism of Homer action on group I mGluRs remains undefined, images of mGluR surface expression can begin to shed light on this process. The principle effect of coexpressing long forms of Homer with group I mGluRs in SCG neurons appears to be the formation of cell surface receptor clusters. Levels of membrane surface-expressed mGluR5 appeared comparable when the receptor was expressed alone or coexpressed with Homer 2b. This is consistent with observations that Homer long forms induce cell surface mGluR clusters in cultured CNS neurons (Ciruela et al., 1999; Tadokoro et al., 1999). This clustering activity contrasts with observations from HeLa and HEK-293 cells in which long forms of Homer act to retain mGluR in endoplasmic reticular pools and reduce cell surface expression of mGluRs (Roche et al., 1999). We anticipate that these different effects of Homer may be attributable to cell-specific expression of accessory proteins that interact with Homer or mGluRs. In contrast to long forms, Homer short forms do not induce cell surface clustering in SCG neurons, indicating that cluster formation is dependent on the C-terminal domain. This suggests a model in which mGluR clusters form on the basis of the physical association of the coiled coil multimerization domain of long Homer proteins.

How might the binding of Homer influence coupling between mGluR and G-proteins? The C-terminal cytosolic tail of group I mGluRs has a demonstrated role in the signaling properties to G-proteins (Prezeau et al., 1996; Mary et al., 1997). One possibility is that the physical presence of the Homer EVH1 domain interferes with the physical association between mGluR and G-proteins. This does not appear to be the case, because coupling of group I mGluR is not affected by expression of short forms of Homer, which do directly bind mGluR. Moreover, the blocking activity of long Homers is reversed by coexpression of short-form Homer. The effects of Homer expression are specific for group I mGluRs, because they do not influence coupling of mGluR2 to the same G-protein-regulated ion channels. This is consistent with the demonstrated binding of the Homer EVH1 domain to group I mGluRs and the absence of binding to other mGluR subtypes. Moreover, Homer is not known to interact with G-proteins or the effector ion channels in this study. Additionally, long forms of Homer did not selectively occlude one G-protein signaling pathway over another (see Fig. 7). Specifically, both $G_{i / o}$ and $\mathrm{G}_{\mathrm{q} / 11}$ effects on voltage-dependent and -independent inhibition of N-type channel function were similarly blocked by long forms of Homer. Long forms of Homer have been demonstrated to limit the mobility of group I mGluRs within the membrane surface and may thereby limit functional access to membranebound, voltage-gated ion channels. This model predicts that "free" group I mGluRs (i.e., those not clustered with long forms
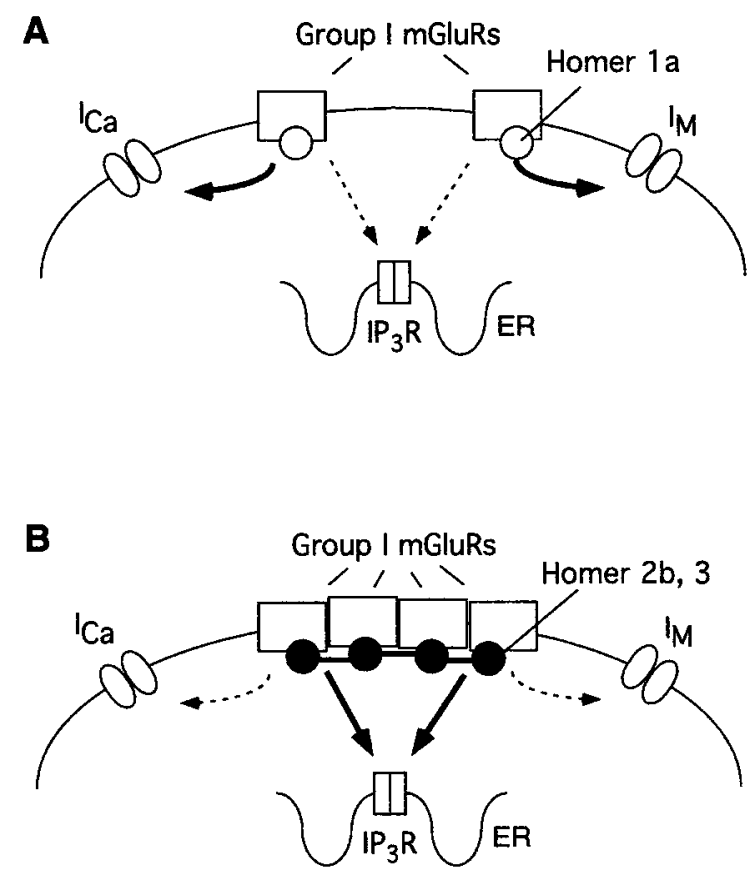

Figure 8. Schematic representation of the proposed mechanism of Homer function. $A$, When Homer 1a associates with group I mGluRs (or without any Homer proteins bound), receptors are diffusely distributed in the membrane. In this state, voltage-gated ion channels on the cell membrane are efficiently modulated, but the calcium signal via mGluRs and the $\mathrm{IP}_{3}$ receptor is weak. $B$, In the presence of long forms of Homer, group I mGluRs cluster together, presumably because of the interaction of the coiled coil, C-terminal tails of Homer. This interaction may also bring the complex in association with the $\mathrm{IP}_{3}$ receptor (schematic not shown). Under this condition, the intracellular calcium signal is strong, but modulation of voltage-gated ion channels is weak.

of Homer) can couple more efficiently to voltage-gated ion channels on the cell membrane (Fig. 8).

Homer $1 \mathrm{~b}$ and $1 \mathrm{c}$ were unexpectedly less effective than Homer $2 \mathrm{~b}$ and 3 in occluding actions of mGluRs (Fig. 3). For example, expression of Homer $1 \mathrm{~b}$ was able to partially reverse the effect of Homer 2b. This result seems to indicate that the partial effect of Homer $1 \mathrm{~b}$ is not simply the result of low expression, because if both were equally active, coexpression of Homer $1 \mathrm{~b}$ and Homer $2 \mathrm{~b}$ would be expected to produce results at least as great as that of Homer $2 \mathrm{~b}$ alone. Thus, Homer 1 long forms appear less occlusive toward group I mGluR signaling to voltage-gated ion channels than Homer 2 or 3 . This difference of activity may provide cells with the ability to "fine tune" mGluR activity. On the basis of the high degree of identity among the EVH1 domain products of the three Homer genes (Xiao et al., 1998), particularly in regions that are consequential for ligand binding (Beneken et al., 2000), and the substantial divergence between their coiled coil domains, it is likely that the difference in efficacy will be attributed to properties of their C-terminal domains. One possibility that is consistent with the mechanisms noted above is that the ability to form stable Homer multimers may be less for Homer 1 long forms than for Homer 2 and 3. Further studies are required to define these mechanisms of Homer action and the extent to which it modifies mGluR I signaling in the in vivo context.

An interesting finding of this study is the relative potency with which Homer $2 \mathrm{~b}$ and 3 were able to occlude calcium current and M-current modulation. Defined injections of the Homer $2 b$ expression construct were able to block calcium current modulation almost completely but were inactive against M-current (Figs. 3 and 6). At higher levels of cDNA injection, effects of mGluR on both currents were occluded. This differential selectivity may result from a greater amplification in the pathway leading to M-current modulation, compared with that of calcium current. In a previous study (Ikeda et al., 1995) in which group I mGluRs were expressed in 
SCG neurons via cytoplasmic mRNA injection, activation of mGluRs appeared to inhibit M-current, whereas calcium currents were unaltered. In retrospect, this result could be explained by a lower level of mGluR expression (compared with that after nuclear cDNA injection, as in the present study) competing with natively expressed Homer 2 and 3. The resulting stoichiometry may have achieved a balance that allowed modulation of M-currents but not calcium currents. The differential sensitivity of the signaling pathways may have a broader importance, because it implies that Homer can selectively regulate the modulation of G-protein signals to different effector pathways.

Previously, we demonstrated that expression of Homer 1a reduced the amplitude and prolonged the time to peak of the intracellular calcium transient induced by activation of mGluR in cultured Purkinje neurons. By contrast, expression of Homer 1b did not alter this response. This differential effect of the short and long forms of Homer was attributed to the ability of Homer short forms to disrupt the physical linkage produced by long forms between $\mathrm{mGluR}$ and the $\mathrm{IP}_{3}$ receptor. Indeed, this linkage can be demonstrated to be disrupted using biochemical techniques in mice expressing the Homer short-form protein. These data provide an interesting contrast to the present study, in which Homer short form coexpression had no effect on mGluR signaling, whereas long forms had dramatic consequences. Among the many differences between the experimental preparations, we note that Purkinje neurons express high levels of Homer 1 and 3 long forms, and responses were evoked by native group I mGluRs. Nevertheless, the results share the general principle of a physiological antagonism between short and long forms of Homer. This comparison also demonstrates that Homer proteins can have reciprocal effects on the group I signal outputs, leading to release of intracellular calcium versus inhibition of membrane ion channels. Long forms of Homer induce receptor clustering that may allow more efficient association with calcium release machinery but functionally isolate the receptors from membrane-associated channels. By contrast, Homer 1a would uncouple mGluRs from $\mathrm{IP}_{3} \mathrm{R}$ and enhance coupling to ion channels on the membrane (see Fig. 8). Differences in the sensitivity of effectors downstream to G-proteins, as demonstrated here between the N-type calcium channel and M-current potassium channel, are expected to further contribute to the consequence of Homer 1a action.

In summary, data from this study demonstrate that Homer $2 \mathrm{~b}$ but not Homer 1a induces cell surface clustering of a group I mGluR. In addition, the long forms of Homer (Homer 1b, 1c, 2b, and 3) can selectively inhibit signaling from group I mGluRs to N-type calcium and M-type potassium channels. This occlusion can be partially reversed by coexpression of Homer $1 \mathrm{a}$ or the deletion construct H2N. Higher levels of Homer $2 b$ and Homer 3 appear to be necessary to occlude M-current inhibition than calcium current inhibition, perhaps because of the amplification of the M-current modulatory pathway. Expression of the long forms of Homer did not selectively occlude specific G-protein pathways activated by group I mGluRs. Perhaps most interesting is the demonstration that Homer proteins evoke reciprocal effects on group I mGluR signals leading to regulation of membrane ion channels versus release of intracellular calcium, suggesting a mechanism by which synaptic activity and the consequent induction of Homer 1a can regulate both the magnitude and predominate output of group I metabotropic glutamate receptors.

\section{REFERENCES}

Bean BP (1989) Neurotransmitter inhibition of neuronal calcium currents by changes in channel voltage dependence. Nature 340:153-156.

Beneken J, Tu JC, Xiao B, Nuriya M, Yuan JP, Worley PF, Leahy DJ (2000) Structure of the Homer EVH1 domain-peptide complex reveals a new twist in polyproline recognition. Neuron 26:143-154.

Brakeman PR, Lanahan AA, O'Brien R, Roche K, Barnes CA, Huganir RL, Worley PF (1997) Homer: a protein that selectively binds metabotropic glutamate receptors. Nature 386:284-288.
Brown DA, Adams PR (1980) Muscarinic suppression of a novel voltagesensitive $\mathrm{K}^{+}$current in a vertebrate neurone. Nature 283:673-676.

Charpak S, Gähwiler BH, Do KQ, Knöpfel T (1990) Potassium conductances in hippocampal neurons blocked by excitatory amino-acid transmitters. Nature 347:765-767.

Chavis P, Shinozaki H, Bockaert J, Fagni L (1994) The metabotropic glutamate receptor types $2 / 3$ inhibit L-type calcium channels via a pertussis toxin-sensitive G-protein in cultured cerebellar granule cells. J Neurosci 14:7067-7076.

Choi S, Lovinger DM (1996) Metabotropic glutamate receptor modulation of voltage-gated $\mathrm{Ca}^{2+}$ channels involves multiple receptor subtypes in cortical neurons. J Neurosci 16:36-45.

Ciruela F, Soloviev MM, McIlhinney RAJ (1999) Co-expression of metabotropic glutamate receptor type 1a with Homer-1a/Vesl-1S increases the cell surface expression of the receptor. Biochem $J$ 341:795-803.

DeWaard M, Liu H, Walker D, Scott VES, Gurnett CA, Campbell KP (1997) Direct binding of G-protein $\beta \gamma$ complex to voltage-dependent calcium channels. Nature 385:446-450.

Elmslie KS, Zhou W, Jones SW (1990) LHRH and GTP-gamma-S modify calcium current activation in bullfrog sympathetic neurons. Neuron 5:75-80.

Glaum SR, Miller RJ (1995) Presynaptic metabotropic glutamate receptors modulate $\omega$-conotoxin-GVIA-insensitive calcium channels in the rat medulla. Neuropharmacology 34:953-964.

Haley JE, Abogadie FC, Delmas P, Dayrell M, Vallis Y, Milligan G, Caulfield MP, Brown DA, Buckley NJ (1998) The a subunit of $\mathrm{G}_{\mathrm{q}}$ contributes to muscarinic inhibition of the M-type potassium current in sympathetic neurons. J Neurosci 18:4521-4531.

Hay M, Kunze DL (1994) Glutamate metabotropic receptor inhibition of voltage-gated calcium currents in visceral sensory neurons. J Neurophysiol 72:421-430.

Herlitze S, Garcia DE, Mackie K, Hille B, Scheuer T, Catterall W (1996) Modulation of $\mathrm{Ca}^{2+}$ channels by G-protein $\beta \gamma$ subunits. Nature 380:258-262.

Hille B (1994) Modulation of ion channel function by G-protein coupled receptors. Trends Neurosci 17:531-535.

Ikeda SR (1996) Voltage-dependent modulation of N-type calcium channels by G-protein $\beta \gamma$ subunits. Nature 380:255-258.

Ikeda SR (1997) Heterologous expression of receptors and signaling proteins in adult mammalian sympathetic neurons by microinjection. In: Methods in molecular biology (Challis RAJ, ed), pp 191-202. Totowa, NJ: Humana.

Ikeda SR, Lovinger DM, McCool BA, Lewis DL (1995) Heterologous expression of metabotropic glutamate receptors in adult rat sympathetic neurons: subtype-specific coupling to ion channels. Neuron 14:1029-1038.

Kammermeier PJ, Ikeda SR (1999) Expression of RGS2 alters the coupling of metabotropic glutamate receptor $1 \mathrm{a}$ (mGluR1a) to M-type $\mathrm{K}^{+}$ and N-type $\mathrm{Ca}^{2+}$ channels. Neuron 22:819-829.

Kato A, Ozawa F, Saitoh Y, Fukazawa Y, Sugiyama H, Inokuchi K (1998) Novel members of the Vesl/Homer family of PDZ proteins that bind metabotropic glutamate receptors. J Biol Chem 273:23969-23975.

Marrion NV (1997) Control of M-current. Annu Rev Physiol 59:483-504.

Mary S, Stephan D, Gomeza J, Bockaert J, Pruss RM, Pin JP (1997) The rat mGlu1d receptor splice variant shares functional properties with the other short isoforms of mGlu1 receptor. Eur J Pharmacol 335:65-72.

McCool BA, Pin JP, Harpold MM, Brust PF, Stauderman KA, Lovinger DM (1998) Rat group I metabotropic glutamate receptors inhibit neuronal $\mathrm{Ca}^{2+}$ channels via multiple signal transduction pathways in $\mathrm{HEK}$ 293 cells. J Neurophysiol 79:379-391.

Peavy RD, Conn PJ (1998) Phosphorylation of mitogen-activated protein kinase in cultured rat cortical glia by stimulation of metabotropic glutamate receptors. J Neurochem 71:603-612.

Pin J-P, Duvoisin R (1995) Neurotransmitter receptors I. The metabotropic glutamate receptors: structure and functions. Neuropharmacology 34:1-26.

Prezeau L, Gomeza J, Ahern S, Mary S, Galvez T, Bockaert J, Pin JP (1996) Changes in the carboxyl-terminal domain of metabotropic glutamate receptor 1 by alternative splicing generate receptors with differing agonist-independent activity. Mol Pharmacol 49:422-429.

Roche KW, Tu JC, Petralia RS, Xiao B, Wenthold RJ, Worley PF (1999) Homer $1 \mathrm{~b}$ regulates the trafficking of group I metabotropic glutamate receptors. J Biol Chem 274:25953-25957.

Sahara Y, Westbrook GL (1993) Modulation of calcium currents by a metabotropic glutamate receptor involves fast and slow kinetic components in cultured hippocampal neurons. J Neurosci 13:3041-3050.

Soloviev MM, Ciruela F, Chan WY, McIlhinney RA (2000) Molecular characterisation of two structurally distinct groups of human homers, generated by extensive alternative splicing. J Mol Biol 295:1185-1200.

Sun J, Tadokoro S, Imanaka T, Murakami SD, Nakamura M, Kashiwada K, Ko J, Nishida W, Sobue K (1998) Isolation of PSD-Zip45, a novel 
Homer/vesl family protein containing leucine zipper motifs, from rat brain. FEBS Lett 437:304-308.

Tadokoro S, Tachibana T, Imanaka T, Nishida W, Sobue K (1999) Involvement of unique leucine-zipper motif PSD-Zip45 (Homer 1c/vesl$1 \mathrm{~L}$ ) in group 1 metabotropic glutamate receptor clustering. Proc Natl Acad Sci USA 96:13801-13806.

Tu JC, Xiao B, Yuan JP, Lanahan AA, Leoffert K, Li M, Linden DJ, Worley PF (1998) Homer binds a novel proline-rich motif and links group 1 metabotropic glutamate receptors with IP3 receptors. Neuron 21:717-726.

Tu JC, Xiao B, Naisbitt S, Yuan JP, Petralia RS, Brakeman P, Doan A, Aakalu VK, Lanahan AA, Sheng M, Worley PF (1999) Coupling of
mGluR/Homer and PSD-95 complexes by the shank family of postsynaptic density proteins. Neuron 23:583-592.

Wang H-S, Pan Z, Shi W, Brown BS, Wymore RS, Cohen IS, Dixon JE, McKinnon D (1998) KCNQ2 and KCNQ3 potassium channel subunits: molecular correlates of the M-channel. Science 282:1890-1893.

Womble MD, Moises HC (1994) Metabotropic glutamate receptor agonist ACPD inhibits some, but not all, muscarinic-sensitive $\mathrm{K}^{+}$conductances in basolateral amygdaloid neurons. Synapse 17:69-75.

Xiao B, Tu JC, Petralia RS, Yuan JP, Doan A, Breder CD, Ruggiero A, Lanahan AA, Wenthold RJ, Worley PF (1998) Homer regulates the association of group 1 metabotropic glutamate receptors with multivalent complexes of homer-related, synaptic proteins. Neuron 21:707-716. 